\section{The (dis)information age}

\author{
Gary K. Meffe
}

Biological diversity and ecosystem health are facing dangerous and uncertain times here in the USA. The usual problems persist, driven by population growth and an out-of-control, consumption-orientated society: habitat loss and fragmentation, air and water pollution, shrinkage of species' ranges, soil erosion, siltation of streams, the spread of exotic species, and so on. But those are old demons with familiar faces, and we are relatively comfortable (if often ineffective) in fighting those enemies, which are well-known and clearly defined. A more insidious and immediate danger lies in other fronts that are hazy, only partly known, and lurk within the darkest shadows of human nature. They are united by a common theme: disinformation, purposely and carefully promoted by a small minority motivated by selfish agendas, short-term thinking, and malignant souls that cannot comprehend either the beauty or utility of an intact natural world.

Politically, the USA is in a foul mood in the mid-1990s. The November 1994 elections swept into power a group of extremely conservative lawmakers, who promote an agenda that clearly is not in the best interests of conservation of biological diversity. Clean air and water statutes, the Endangered Species Act, the National Environmental Policy Act and other environmental regulations are all under major assault, with real possibilities that they will be demolished. More than 25 years of progress toward making the environment safer both for humans and the rest of biological diversity is in grave danger of being lost within the next year. Driving this, or being driven by it (cause and effect are unclear), is a citizenry that is revolting against government control of any type, motivated by a simple desire (a dangerous thing in a complex world) to cut taxes and extract government from citizens' lives.

A part of this citizen revolution pertinent to land use and conservation is driven by an organization known as the 'Wise Use' group.
This is a collection of private landowners - especially ranchers, farmers, those in the timber and mining industries, developers and others with strong commodity interests - who feel that there is too much government interference in how they use 'their' land (even though many of their activities are on public land, supported by taxpayers). One of their goals is to reduce or eliminate environmental regulations because, they feel, such regulations interfere with their rights (apparently without responsibilities) as landowners to treat their land as they see fit. Thus, they would like to see the Endangered Species Act and wetland protection laws eliminated, for example, because this would allow them to proceed with development or timber harvest or mining in areas that currently experience some regulation.

Much of the success enjoyed by groups such as this has been enabled by a series of disinformation campaigns that distort scientific truth in a way that is convincing to any citizen who puts only superficial thought into it. This is borne out by Representative Wayne Gilchrest (Maryland), who told the Baltimore Sun newspaper that it has been difficult to work with his Republican colleagues on environmental issues (ESA Today, 2 May 1995). 'I have never seen so many people afraid of information in my life [or] so extravagantly funded by interest groups that stand to make a lot of money from misinformation.' For example, the ultra-conservative author and radio and talk show host, Rush Limbaugh, has been a central figure in orchestrating anti-environmental sentiment in this country. Relying on emotional terms including "environmental wackos', 'alarmists and prophets of doom' and 'Algore' (for our Vice President and author of Earth in the Balance), he has successfully convinced a large group of Americans that environmental concerns are a hoax perpetrated by scientific 'kooks' whose religion is the environment. Although his distortions and lies have been clearly refuted by the scientific community (for example Haimson et al., 1995), his efforts nevertheless motivate many Americans to lobby their political leaders to reject virtually all environmental protection. 
Another example involves fringe political figure Lyndon LaRouche, whose anti-governmental rhetoric has been heard for decades. One of his followers, Rogelio Maduro, has nearly single-handedly placed the USA's ratification of the Rio Biodiversity Treaty in jeopardy (Washington Post, 23 April 1995). Through absurd statements that the treaty would turn the USA over to the UN, which would then dictate its environmental, social and moral standards, or that the treaty 'effectively mandates signatory nations to turn nature worship into their state religion', he has mobilized angry forces that have lobbied Congress strongly and changed the voting perspective to the point that the treaty is in serious jeopardy. He stated that 'Protection is not the objective [of the Biodiversity Treaty]...Power and control is the objective. The treaty shifts the power to the UN. We cannot allow this. If it passes we are really in trouble. We will be governed by New York City and the United Nations. Get a FAX alert going.' LaRouche has also stated that environmentalists want to kill off a significant portion of the world's human population in the name of protecting plants and animals. Such emotional and bizarre diatribe merely serves to polarize humanity into an 'us vs. them' mentality at a time when unity of purpose is most desperately needed.

The anti-government mood and hatred of regulation apparently contributed to the recent and tragic bombing of a federal building in Oklahoma City, killing 168 people, including 19 children down to 6 months of age. Paramilitary groups have formed, with the apparent goal of 'protecting' themselves against a government whose intention (they believe) is to strip away many of their rights. Rest assured that many of these people generally do not favour environmental regulations to protect biodiversity.

These examples lead to sober reflection indeed, not only of deterioration of the human condition in these confusing times with an increasingly crowded planet and dwindling resources, but of the outlook for biological diversity and natural habitats. In a world in which human beings willingly lie and even kill innocents in the name of ideological gain or amassing personal wealth, can we expect much compassion and energy for the remaining 30 million or so species struggling to merely exist? When an already ideologically polarized society states that protection of human health and the environment is a religion promulgated by 'kooks', is there room for optimism? Is there any reason to believe that we can make something of the ecological mess we have created since the industrial revolution? I suggest two possibilities for now.

First, the majority of people, I think, remain reasonable, and do not want an ecologically deteriorating world for their descendants. Reason can prevail, if given an opportunity to be heard. Every current poll in the USA tells of a strong commitment to environmental protection. Even in my adopted state of South Carolina, a generally poor and undereducated region, $60-75$ per cent of respondents to a recent poll indicated strong support for protection of endangered species, wetlands and water quality, even if it meant fewer jobs and less economic development. The political leaders and media hate-mongers must be made to understand that.

Second, misinformation has a finite lifespan. Eventually, it is rooted out and exposed for what it is. Reasonable, thoughtful people with a perspective beyond immediate personal gain (and I have to believe this still portrays the majority of Americans) will ultimately reject the simple-minded nonsense promoted by a small minority of opportunists. I believe that the pendulum will swing back toward reasoned thought and intelligent analysis of our predicaments on the planet. Information based on objective scientific study must replace disinformation if we are to continue the gains in environmental and human health made in recent times. If not, we will further regress into a parasitic relationship with the planet, and future generations will pay the high costs that will accrue from the Disinformation Age.

\section{Reference}

Haimson, L., Oppenheimer, M. and Wilcove, D. 1995. The Way Things Really Are. Environmental Defense Fund, New York, NY. 